\title{
西瓜種子の Citricodehydrase.
}

\author{
渡邀門

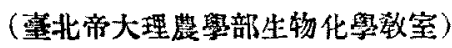 \\ 昭和 11 年 7 月 14 日受理
}

植物種子中には動物組織中と可成摄を異にした Dehydrase が仿在する。Thunberg(1) (1929)

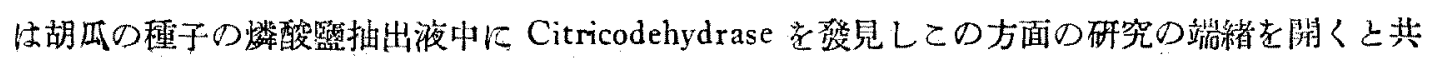
に之老枸緣酸の微量定量に利用した。其後植物種子の Citricodehydrase は主として Thunberg

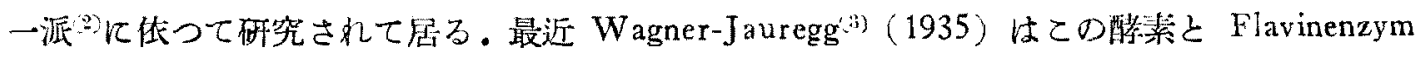

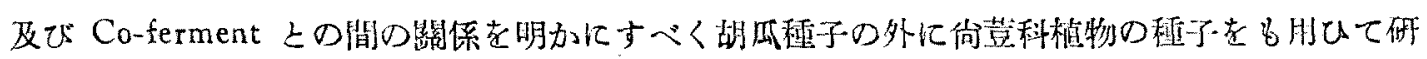
究して居る。

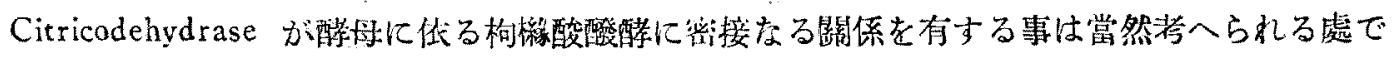
Müller (1934) は Mazerationssaft 中にこの酵素の存在する事考證朋せり。

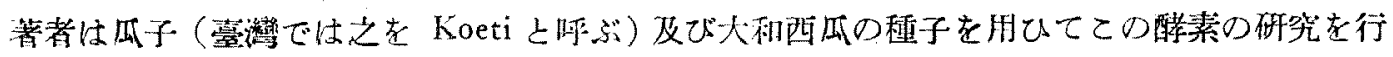

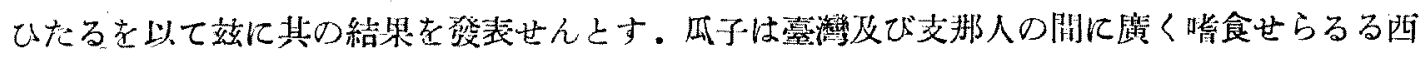

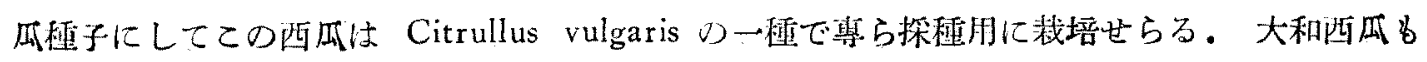

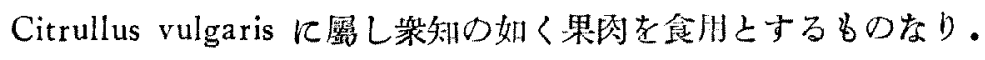

\section{害 驗の、部}

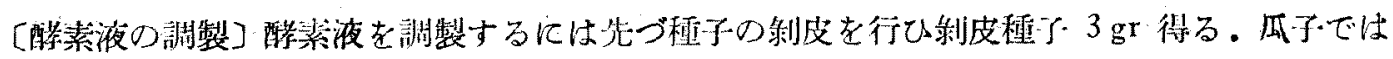

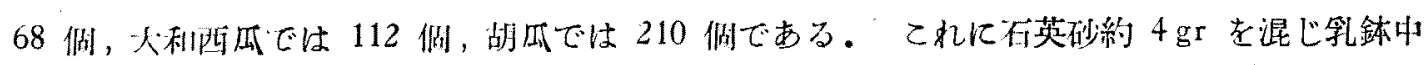

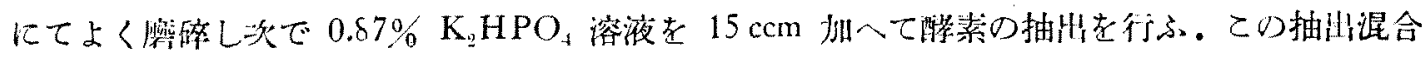

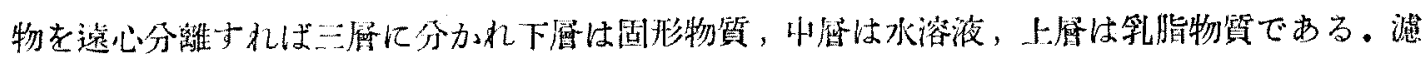

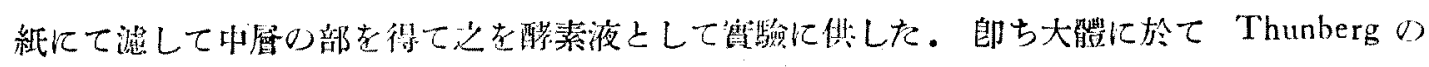
行ひたる方法に依れり。

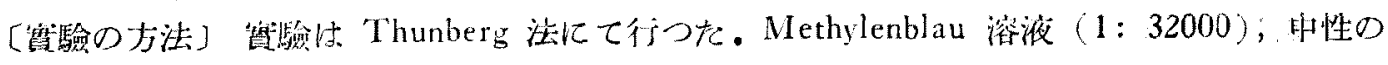

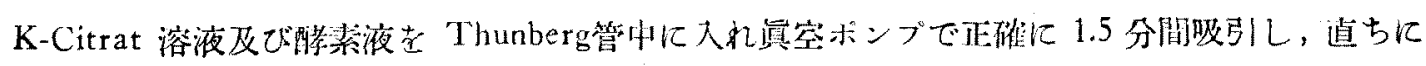

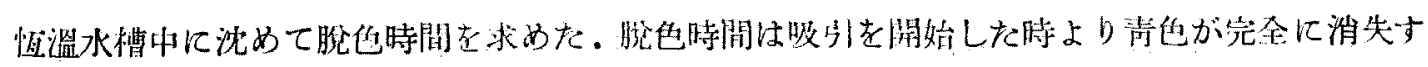
る迄の時間老以て示した。

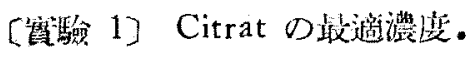

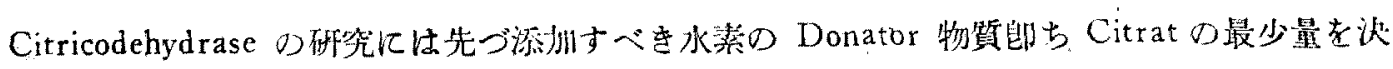

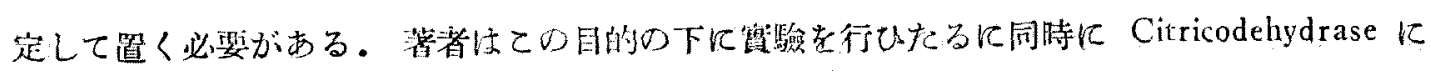

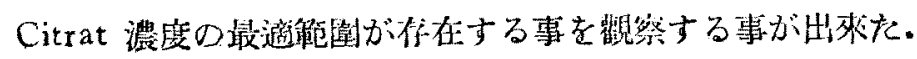


4 倠の Thunberg 畄江 Methylenblau 溶液 $0.3 \mathrm{ccm}$, 程及の濃度の Citrat 溶液 $0.5 \mathrm{ccm}$ 及

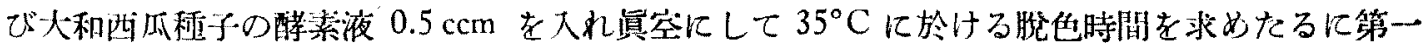
表の如き結果となれり。

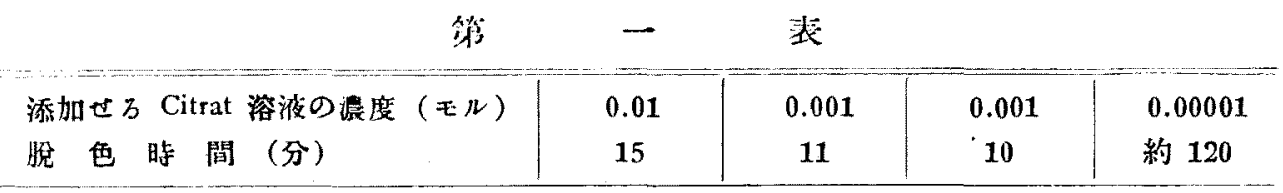

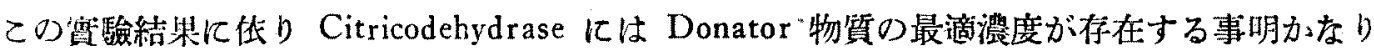
次でての最適濃度の範園を更に詳しく碓めんとし $0.0001 \mathrm{M}$ 溶液を用ひて第二表に示せる如く

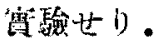

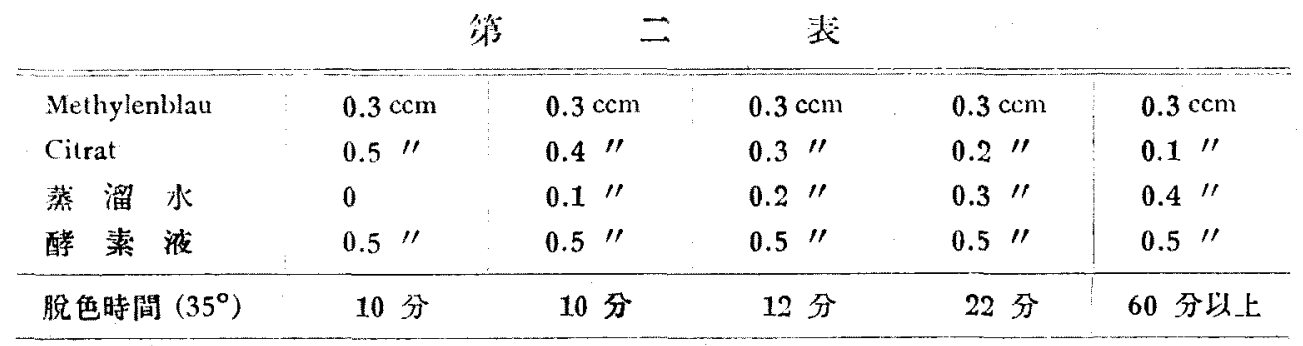

卙ち添打すべきDonator 物質の最適澧度は $0.0001 \mathrm{M}$ 溶液 $0.4 \mathrm{ccm}$ 以上 $0.001 \mathrm{M}$ 溶液 0.5 com 以下の範圍に存在する事を知れり。

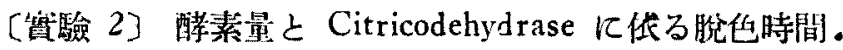

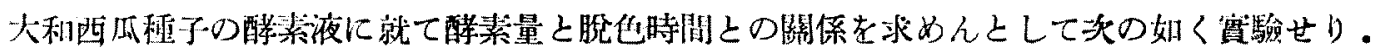

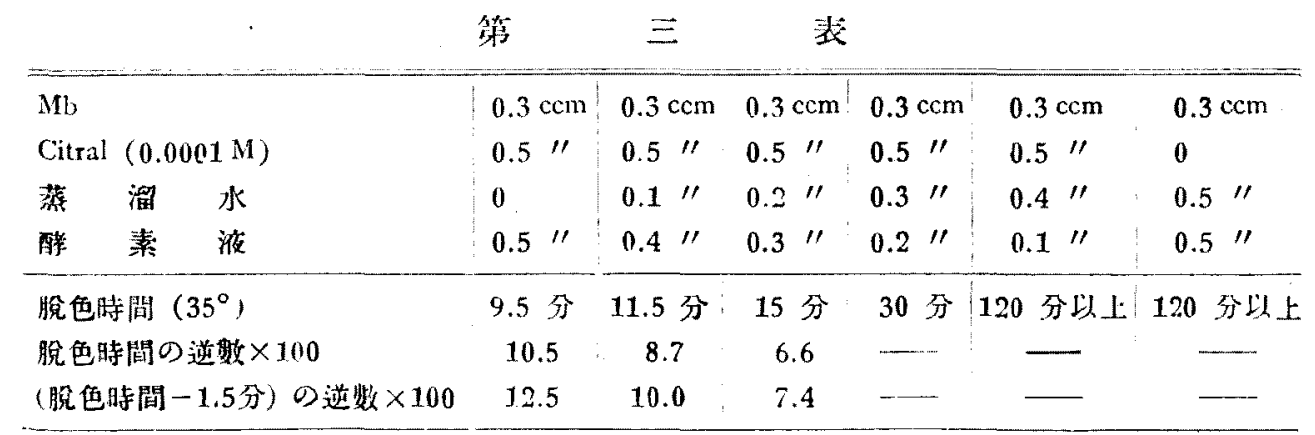

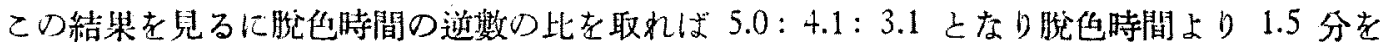
減したるるのり逆䧶の比は $5.0: 4.0: 3.0$ となる。

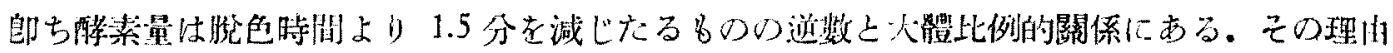

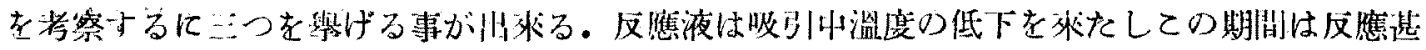

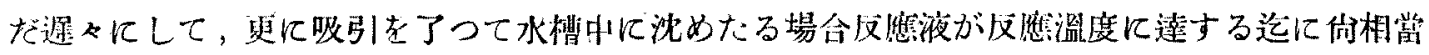

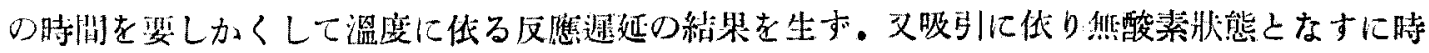




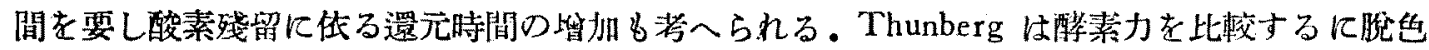

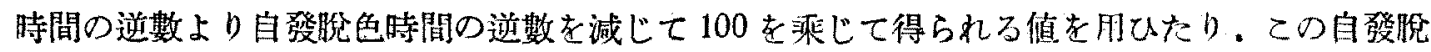
包現象を考虑に入れる必要あるも之に就ては挠に述べる事にする。

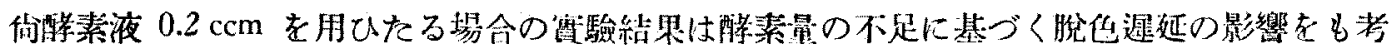
虙せねばならないので之を雀をたり。

〔賽驗 3〕酵素液の抽出に就て。

酸碎せる制皮栢子（大和西瓜） $3 \mathrm{gr}$ 在先づ $0.87 \% \mathrm{~K}_{2} \mathrm{HPO}_{4}$ 溶液 $15 \mathrm{ccm}$ 亿て抽出し，次で 周形殘查に就て耐び $0.87 \% \mathrm{~K}_{2} \mathrm{HPO}_{4}$ 溶液 $15 \mathrm{ccm}$ を加へて第 2 回の抽恬を行ひ，兩抽出液に

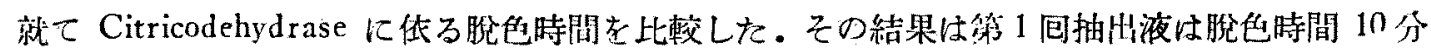

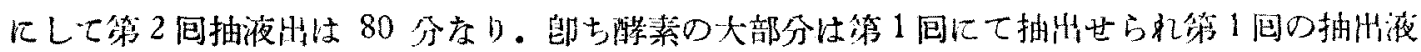
にて Citricodehydrase 作用の比較定量を行ひ得る事確めたり。

[實驗 4]、程々の溫度に於ける Citricodehydrase 作用。

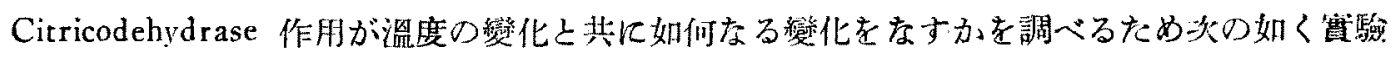
Lた.

Methylenblau 溶液 $0.3 \mathrm{ccm}, 0.001 \mathrm{M}$ citrat 溶液 $0.1 \mathrm{ccm}$, 蒸溜水 $0.5 \mathrm{ccm}$ 大和西瓜の醉素

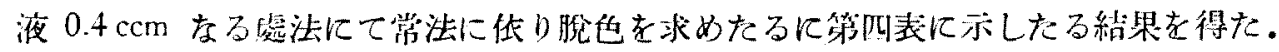

\begin{tabular}{|c|c|c|c|c|c|}
\hline 測 定溫度 & $35^{\circ}$ & $45^{\circ}$ & $55^{\circ}$ & $57^{\circ}$ & $60^{\circ}$ \\
\hline 脫色時間 & 11 分 & 9.5 分 & 9 分 & 9 分 & 脱色せす \\
\hline
\end{tabular}

垖ち Citricodehydrase 作用は溫度 $55 \sim 57^{\circ} \mathrm{C}$ に至るまでは溫度の上暴と共に反隹速度嘴加し $60^{\circ} \mathrm{C}$ になれば消头する。

[實驗 5] Citricodehydrase D安定度.

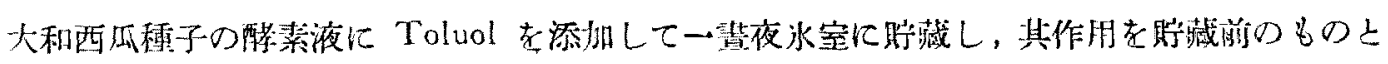
比較したるに次表に示せる結果索得た。

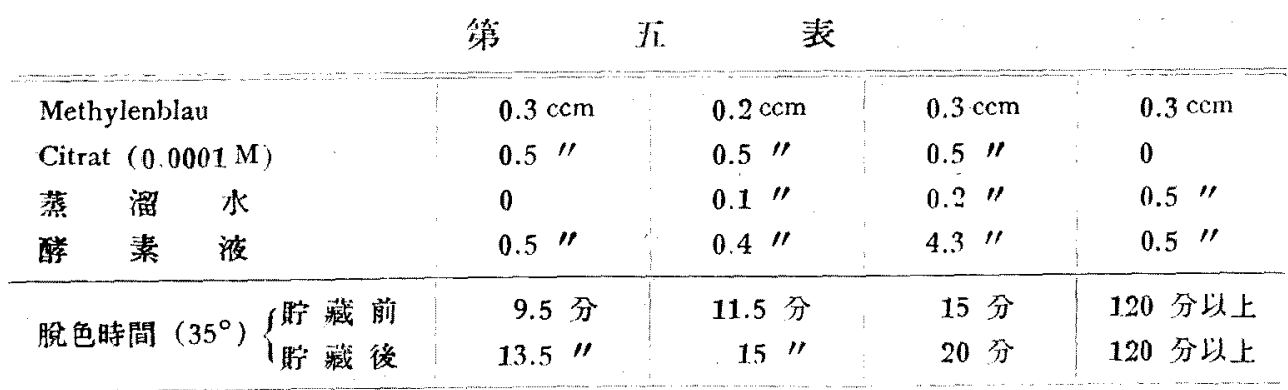

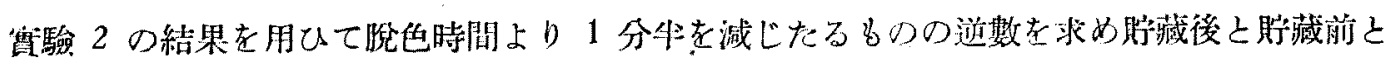

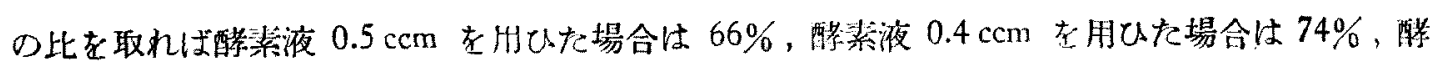


素液 $0.3 \mathrm{ccm}$ を用ひたる場合は 73\%となる.印ち酵素作用は眝藏前の約 $70 \%$ に低下を示せり。

[實驗 6] Methylenblau の代りに他の Redox 指示藥を用ひた場合。

通常 Dehydrase の矿究には Methylenblau が水素の Acceptor こして用ひられるが，著者は Methylenblau の代りに Indigo 系統の Redox 指示樂考用ひて Citricodehydrase の赛驗を行ひ をるに Indigo-tetrasulfonate, Indigo-trisulfonate, Indigo-disulfonate 仕何れも還元されて是等 は水素の Acceptor となり得る事を確めたり。郎ち Citronensäure-Dehydrase-Oxycitronensäure の system に於ける potential はェ $\mathrm{H}=7.5$ 以下に存在する。

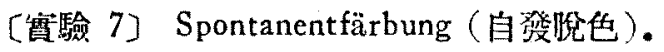

Methylenblau 溶液は Citrat を添玑しない場合でも愫素液に位つて還元される，Thunberg は Citricodehydrase の强さを示すに $J=(1 / A-1 / B) \times 100$ なる式を用ふる事を提案した。此 處に $J$ は Citricodehydrase の强さで $A$ は Citrat が存在する場合の脳色時閒で $B$ は Citrat が無い場合の㧤色時間である.故に $1 / B$ の項は自發脱色の强さを示するのである。

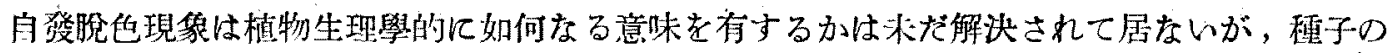
呼吸に重大なる關係のある事は當然である、今自發肹色に就て著者の少しく研究せる處を迹べ て見る。

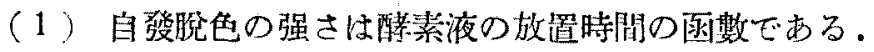

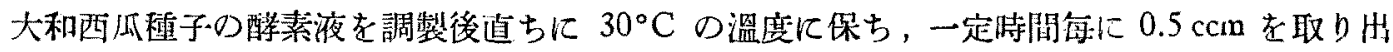
して Methylenblau 溶液 $0.3 \mathrm{ccm}$ ，蒸溜水 $0.5 \mathrm{ccm}$ を大れたる Thunberg 管中に加一顛空とな し $35^{\circ} \mathrm{C}$ に於ける自發肘色の時間を檢したるに次の結果を得だ。

\begin{tabular}{|c|c|c|c|c|c|c|}
\hline 放置時間 & 3 分 & 8 分 & 16 分 & 27 分 & 32 分 & 46 分 \\
\hline 脫色時間 & $15^{\prime \prime}$ & $31 " \prime$ & $82 \prime \prime$ & $114 "$ & 148 分 & $164 "$ \\
\hline
\end{tabular}

節ち自發脫色作用は放䝵すれば急激沉消失する。

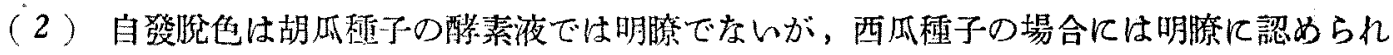
殊に瓜子の場合では非常に䫏著である。

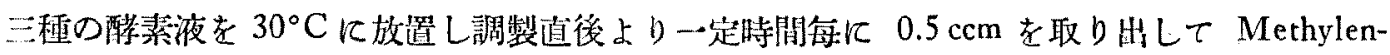
blau 溶液 $0.3 \mathrm{ccm}$, 蒸溜水 $0.5 \mathrm{ccm}$ を大れたる Thunberg 管中に添执し, 真室にして $35^{\circ} \mathrm{C} に$ て脚色特閏を检したるに次表の如き結果を得た。

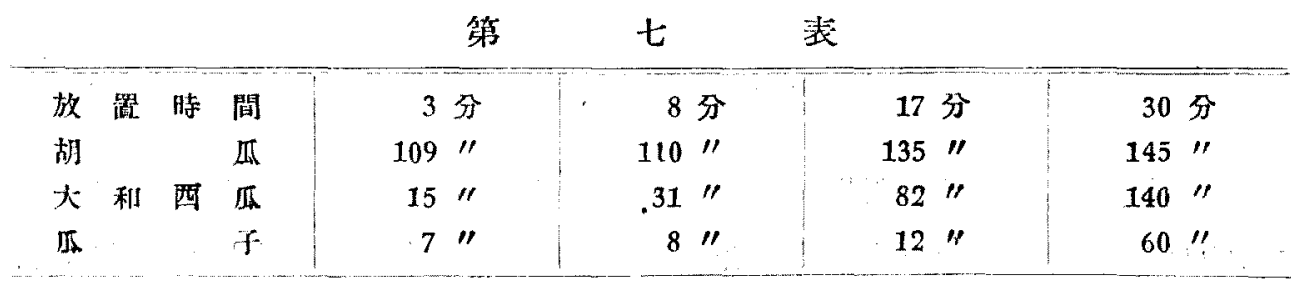




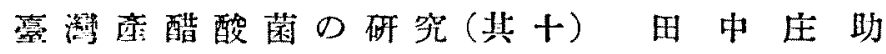

\begin{tabular}{|c|c|c|c|c|c|c|}
\hline 真 & & & 行 & 列 & 設 & 正 \\
\hline 733 & 下 & より & 10 & 3 & 30 & $30^{+}$ \\
\hline 733 & & $"$ & 5 & 2 & 88 & 80 \\
\hline$" \prime$ & & " & 2 & 3 & 136 & 134 \\
\hline 736 & & $"$ & 8 & 9 & 55 & $55^{+}$ \\
\hline 737 & 上 & L v & 3 & 9 & 20 & $20^{+}$ \\
\hline$\prime \prime$ & 下 & $2 y$ & 19 & 2 & 115 & 155 \\
\hline$" \prime$ & & $"$ & 1) & 9 & 12.7 & $12.7^{+}$ \\
\hline 740 & 上 & より & 12 & 3 & 27.5 & $87.5^{+}$ \\
\hline$"$ & 下 & より & 2 & 1 & 90 & 92 \\
\hline " & & $" \prime$ & 1 & 2 & 35 & 345 \\
\hline 741 & 上 & より & 20 & 7 & 131 & 135 \\
\hline 743 & & $\cdot$ & 20 & 9 & 7.02 & 9.02 \\
\hline$" \prime$ & & " & 21 & 9 & 10.78 & 10.98 \\
\hline$\prime \prime$ & & $"$ & 25 & 7 & $\sim 2.76$ & $\sim 2.75$ \\
\hline$" \prime$ & & $"$ & 32 & 9 & 7.45 & 9.45 \\
\hline 744 & & & 文 潡 & (6) & $13(1935)$ & $13,1017(1935)$ \\
\hline$\prime \prime$ & & & " & (7) & (1935) & $(1936)$ \\
\hline
\end{tabular}




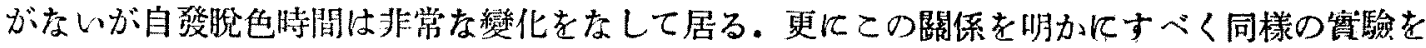
$45^{\circ} \mathrm{C}$ に放䈯したる場合に就て行ひ次表の結果を得た。

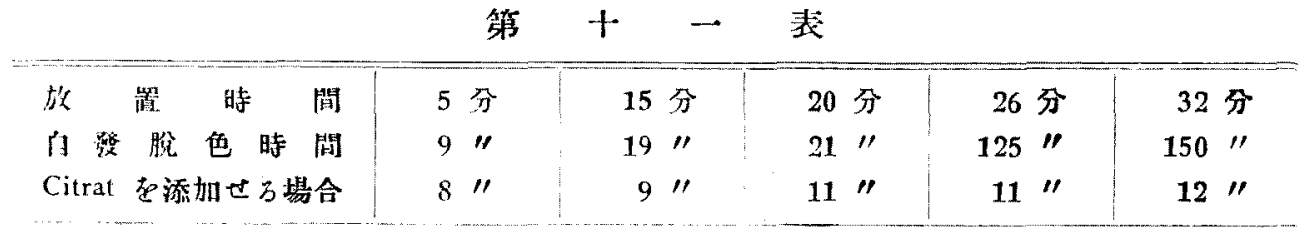

第十一装に示されたる結果を Thunberg の提唱せる $J=(1 / A-1 / B) \times 100$ なる式に適朋し て Citricodehydrase 作用を求されば次表の如くなる。

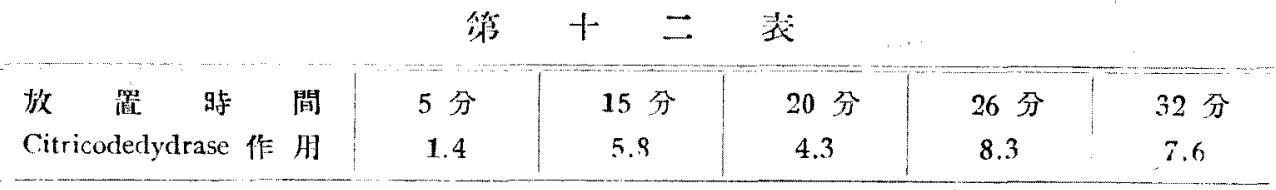

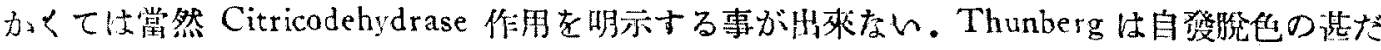

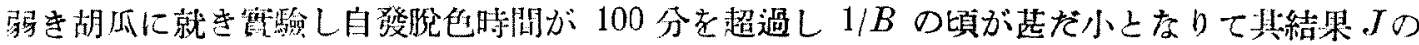

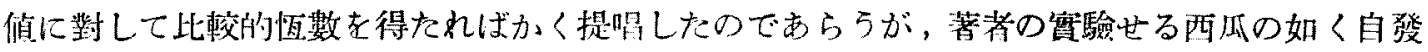

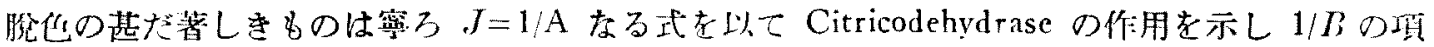
走少くのが赏なりと考へられる。

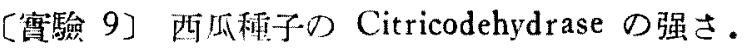

以上の鲾驗絬果より著者は $30^{\circ} \mathrm{C}$ に於ける西瓜程子の Citricodehydrase 作朋圭以下に示士 如くにして求め同時に之を胡瓜種子の場合と比較せり。

Thunberg 息に Citrat を添加する場合には Methylenblau 液 $0.3 \mathrm{ccm}, 0.001 \mathrm{M}$ Citrat 溶液

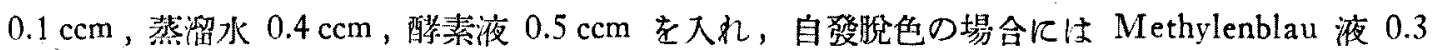

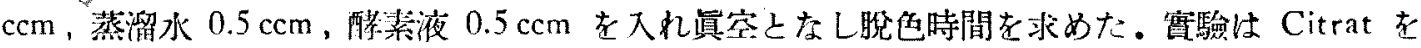

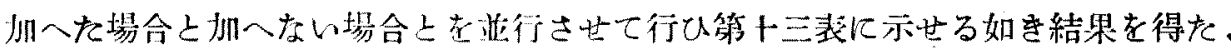

\begin{tabular}{|c|c|c|c|c|c|}
\hline 赫 & $\begin{array}{l}\text { Citrat 添加の場合 } \\
\text { 白橃脱色の場合 }\end{array}$ & $\begin{array}{r}16 \text { 分 } \\
128 "\end{array}$ & 16 分 & $\begin{aligned} & 16 \text { 分 } \\
& 200 "\end{aligned}$ & $\begin{array}{c}17 \text { 分 } \\
200 \text { 分以上 }\end{array}$ \\
\hline 大和西瓜 & $\begin{array}{l}\text { Citrat 添加の場合 } \\
\text { 自發脫色の場合 }\end{array}$ & $\begin{array}{l}12 \text { 分 } \\
17 " \prime\end{array}$ & $\begin{array}{r}14 \text { 分 } \\
137 "\end{array}$ & $\begin{aligned} 16 & \text { 分 } \\
260 " & \end{aligned}$ & $\begin{array}{c}16 \text { 分 } \\
300 \text { 分以上 }\end{array}$ \\
\hline$f$ & $\begin{array}{l}\text { Citrat 添加の㙋合 } \\
\text { 自墢璄色の場合 }\end{array}$ & $\begin{array}{ll}8 & \text { 分 } \\
9 & 11\end{array}$ & $\begin{array}{r}9 \text { 分 } \\
15 " \prime\end{array}$ & $\begin{array}{l}11 \text { 分 } \\
53 \text { " }\end{array}$ & $\begin{array}{r}11 \text { 分 } \\
125 " \prime\end{array}$ \\
\hline
\end{tabular}

これょりCitricodehydrase 作用を求さるには胡瓜の場合は16分，大和西瓜の場合は12 分，

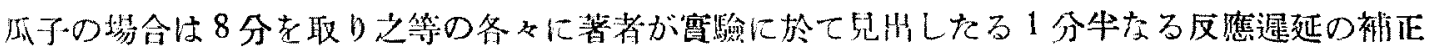
を施してその近數を求め之に 100 を乘じたり。 
斯くして胡瓜種子にては 6.9 ，大和西瓜種子にては 9.5 ，瓜子にては 15.4 なる檤を得る。郎

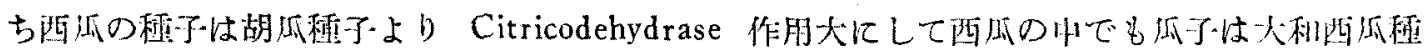
子・尗为大り。

\section{總括}

西瓜檑子の Citricodehydrase汇就て研究し二会の結果老得た。

(1) Citricodehydrase には水絜の Donator である Citrate の澧度の Optimum が住在し Methylenblau 溶液 (1:32000) $0.3 \mathrm{ccm}$ に對して $0.0001 \mathrm{M}$ 溶液 $0.4 \mathrm{ccm}$ 以上, $0.001 \mathrm{M}$ 溶 液 $0.5 \mathrm{ccm}$ 以下の籍圍の量を加へたる時江最速なり。

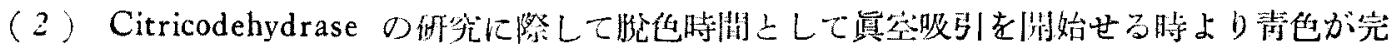

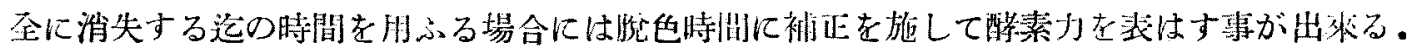
垖ち脫色時間上り 1.5 分を減じて其迹數を取ればての值は酵猄量に比例する。

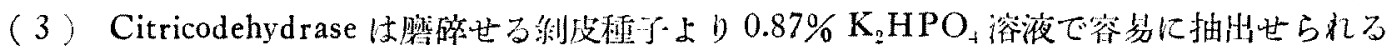

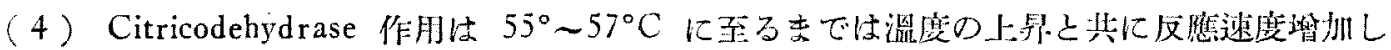
$60^{\circ} \mathrm{C}$ に病れば消失する。

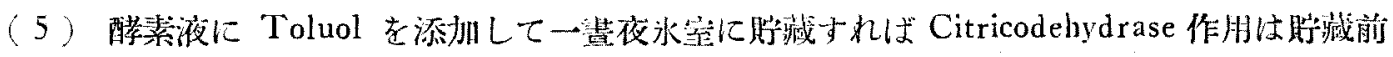
い約 70\% に低下する。

（6） Citricodehydrase には 水素の Acceptor として Methylenblau の代りに他り Redox

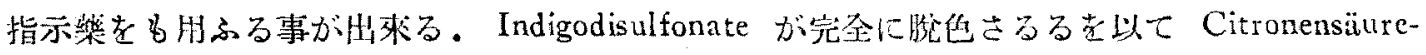
Dehydrase-Oxycitronenäure の系の Potential 恃 $\mathrm{rH}=7.5$ 以下化ある事を知る。

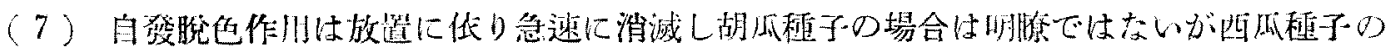

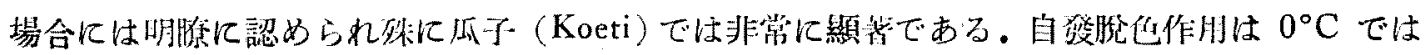

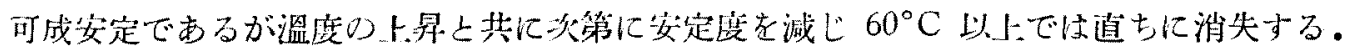

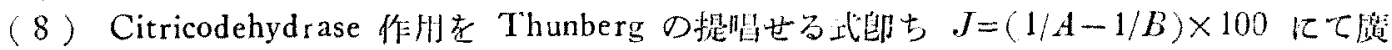

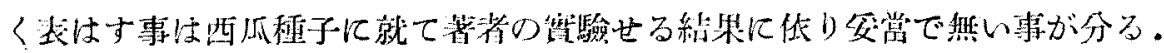

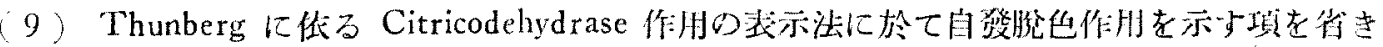

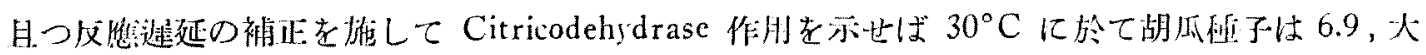

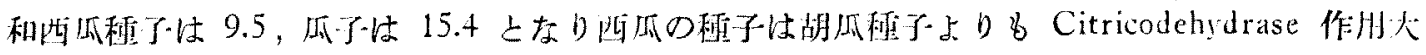
にして瓜子は殊に大なり。

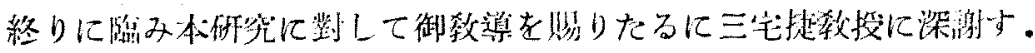

\section{引用文 獻}

(1) Thunberg: Biochem. Zs, 206, 109, 1929.

(2) Broman: Skand. Arch. f. physiol., 64, 171, 1932.

(3) Wagner-Jauregg: Z. f. Phisiol. Chem., 23?, 215, 1935.

(4) Müller: Biochem. Zs, 268, 152, 1934. 